\title{
Episodes from the confessional history of Alaska: Nikolay Ziorov's missionary service
}

\author{
Vladimir Kalinovsky ${ }^{1, *}$ \\ ${ }^{1}$ Candidate of historical sciences, Institute of History, St. Petersburg State University, Russian Federation
}

\begin{abstract}
The paper deals with one of the outstanding hierarchs of the late $19^{\text {th }}-$ early $20^{\text {th }}$ century Nikolay (Ziorov) and his missionary activity in Alaska. It is noteworthy that the peculiarity of his Ministry was that a diverse national staff distinguished all three departments that he led (Aleutian, Taurida, Warsaw and Privislenskaya), so he had to defend the rights of the Orthodox population and to try to harmonize interethnic relations at the level of his ideas. The path of Nikolay (Ziorov)'s Episcopal Ministry began with the appointment in 1891 to the Aleutian diocese, which was responsible for all Orthodox parishes in North America, including Alaska. When Nikolay (Ziorov) arrived in the United States, the local Church Department was located in San Francisco, which made it impossible for the Bishop to have a regular presence in Alaska. Moreover, even the possibility of moving the Department to Alaska was not considered acceptable, since the conversion of the Uniate population living in other States was seen as more promising perspective for the Hierarch at that time. It is established that the Bishop traveled a lot in Alaska, advocated for the rights of the Orthodox population, had a diary and appealed to central and regional authorities. At the initiative of the Minister, the sacred texts were translated into the languages of the indigenous peoples of the region. The views that Nikolay (Ziorov) developed while serving in North America were continued in his later work in other dioceses. Largely, this affected inter-ethnic and inter-religious relations. In both Taurida and Warsaw dioceses, he positioned himself as a defender of the Orthodox faith among the gentile environment. It is shown that Nikolay (Ziorov) used the methods of missionary work, developed in Alaska, later in Taurida and the Kingdom of Poland.
\end{abstract}

\section{Introduction}

Archbishop Nikolay (Ziorov) is one of the undeservedly forgotten hierarchs of the Russian Orthodox Church. During his lifetime, he had a reputation as an active church administrator and missionary, a defender of the interests of Orthodoxy in the State Council of the Russian Empire. Yet, after his death, the name of the Minister was long forgotten. Only in the last few decades there have appeared studies that allow us to understand the scale of the personality of Nikolay (Ziorov) and the place of the Archbishop in the church and political processes of the late 19 th - early 20 th century $[1 ; 2]$. The peculiarity of the Hierarch's Ministry was that all three departments that he led (Aleutian, Taurida, Warsaw and Privislenskaya) were distinguished by a diverse national staff, so he had to defend the rights of the Orthodox population and to try to harmonize inter-ethnic relations at the level of his ideas. It is important to note that the influence of the clergy on socio-political processes and inter-confessional relations in the regions has become an urgent and important topic in modern humanitarian research $[3 ; 4 ; 5]$.

In addition, all three places of Nikolay (Ziorov)'s service are closely connected with the so-called sacred geography, which is often understood as a system of knowledge about the correlation of certain objects on the earth's surface with the categories of sacred or related to religious cults. From this point of view, Alaska is a place where Russian missionaries brought Orthodoxy, as a territory that ceased to be part of Russia, but did not lose its Orthodox community. The Crimea is traditionally perceived as the place of the baptismal font of Prince Vladimir the Great, where Christianity was spread from throughout Russia. During the Russian Empire, many saw orthodox churches in the Kingdom of Poland as islands of «Russianness» in the Catholic environment. It is all the more important to trace the characteristics of activities of the one person who served in three such different regions.

\section{Main part}

The path of the Episcopal Ministry of Nikolay (Ziorov) began in 1891 with his appointment to the Aleutian diocese, which was responsible for all Orthodox parishes in North America, including Alaska. However, all his achievements here were in the shadow, largely due to the fact that his successor in the Aleutian Department in 1898 was the future Patriarch Tikhon (Bellavin). Many achievements of Nikolay (Ziorov)'s pastoral activity

\footnotetext{
* Corresponding author: v.klalinovsky@spbu.ru
} 
were attributed to this more famous Hierarch. The objective assessment of the Orthodox hierarchs' activities in North America is an important task for researchers of the Church mission outside of Russia.

When Nikolay (Ziorov) arrived in the United States, the local Church Department was located in San Francisco, which made it impossible for the Bishop to have a regular presence in Alaska. Moreover, even the possibility of moving the Department to Alaska was not acceptable, since the conversion of the Uniate population living in other States was seen as more promising for the Hierarch at that time. In a letter to his powerful patron, Metropolitan Palladius (Raev) of Saint Petersburg and Ladoga, dated January 9 (21), 1893, Niolay (Ziorov) explicitly pointed this out: "The case of the Uniates requires a serious and speedy discussion and decision. If we lose a favorable moment, it will be impossible to do this with proper success.

Therefore, it will be better to move the bishops' chair not to Sitka (Sitka, Sitkha, New Archangelsk were different names of the city in Alaska, the center of Russian America - author of the paper) but to the Eastern States where there are Russian Uniates... Chicago would be fine, but Washington or New York would be even better. " [6] The same letter also referred to the tasks the Aleutian Bishop was facing: "It is necessary to change the entire clergy staff, it is necessary to enlarge the number of the clergy members in some parishes, it is needed to open several new parishes, schools are needed" [7].

However, the remoteness of Alaska from the main seat of the Bishop did not mean that the Bishop did not care about the situation in the northernmost part of the diocese entrusted to him. The pressing problems of the region's parishioners were well known to him. In another letter to Metropolitan Palladius (Raev), dated July 13 (25), 1893, he named some of them: "about the Junovsky state, about mobile missionary camps - about the return of 3,324 dollars, i.e. almost 7,000 rubles illegally captured from the Church of St. Paul's by the government agents (the case has been going on for almost a year), about the terrible harassment by the Presbyterian and Methodist missions in the Aleutian Islands, etc. All this lies for years without movement, and yet, every minute here does not require delay... I'm spinning around like a squirrel in a wheel: sometimes I get extremely irritated and angry, because I'm deprived of the most necessary things and have to do everything myself... "(all the underlining in this and subsequent quotes were made by Nikolay (Ziorov) [8].

The remoteness of Alaska from San Francisco required Nikolay (Ziorov) to travel to the Northern territory. The first of these took place in May - August 1892. In a letter to Metropolitan Isidore (Nikolsky) dated August 8 (20), 1892, the Bishop of Alaska reported on the route of his trip, which took two months and twelve days. According to the Bishop's calculations, during this time he traveled more than 12,000 miles by water and land. From San Francisco, Nikolay (Ziorov) took a steamer to Unalashka, from where he proceeded to the island of St. Paul and the Mikhailovsky Redoubt. The Bishop was also supposed to visit Quipos mission unattended by any Orthodox Bishops since its foundation. However, the local priest Zachary Belkov, whom Nikolay (Ziorov) described as "crafty and selfserving", the owner of a steamer that operated on Kvikhpahhy, refused to support this initiative. From Mikhailovsky redoubt, the Bishop returned to Unalashka on the boat, and visited Belkovskoye, Unga, Kodiak, Nuchek, Yakutat and Sitka. After staying in Sitka for a week, Nikolay (Ziorov) departed for the island of Kilisna and to the city of Juno, from where he returned to San Francisco.

He described his trip to Alaska the following way: "My journey was very difficult: I had to experience both cold and hunger, storms and moral suffering... There was a storm in the Bering sea for five days - and we literally did not eat or drink during this time; between Kodiak and Yakut, for two days the waves attacked our steamer, breaking into the cabin - through the windows and doors. <...> I cried several times both from cold and hunger" [9]. However, the most difficult conditions did not stop the active Hierarch.

The chief Prosecutor of the Holy Synod, K. P. Pobedonostsev, paid great attention to Nikolay (Ziorov)'s trips in Alaska. A large number of letters from this statesman to the Bishop of Alaska have been deposited in the Russian state historical archive. Following the results of the Hierarch's first trip to Alaska, in September 1892, K. P. Pobedonostsev wrote to Nikolay (Ziorov): "We should try to improve the situation at least a little - but this work requires a lot of effort, time and money. Your appointment is giving us hopes, which we have not had for a long time. For the good of the diocese, I still think it would be even more useful to have its center in Sitka: for the time being, the most important thing for us is to keep Reverend Innokentiy's flock... (i.e. Innokentiy (Veniaminov), Archbishop of Kamchatka, Kuril and Aleutian in 18401868 - by the author of the paper)" [10]. Thus, the chief Prosecutor saw the Orthodoxy centers preservation in Alaska among the primary tasks for Nikolay (Ziorov). He also considered the Episcopal chair transfer directly to the region as a tool for this.

K. P. Pobedonostsev's reaction to another letter with news from Alaska was as follows: "Thank God, things are moving in our way - if only they don't stop. Good news about the Brotherhood opening in Sitkha. Truly, the harvest opens to the mission - if only we could get the doers. We will try - God help us" [11].

Demonstrating his disposition, in 1896, K. P. Pobedonostsev encouraged Bishop Nikolay having promised to provide a warship for a trip to Alaska, about which the chief Prosecutor informed both the Emperor and Admiral N. M. Chikhachev, who at that time was in charge of the Maritime Ministry. However, the promise was not to be fulfilled. Due to political complications in Korea and Japan, it was impossible to allocate one ship from the Russian squadron stationed there to meet the needs of the clergy [12].

Based on the results of his first trip to Alaska and the Aleutian Islands, Nikolay (Ziorov) prepared a diary, which was sent to St. Petersburg, where it was first published on the pages of «Tserkovniye vedomosti 
(Church Bulletin)» magazine and then in a separate publication [13]. A spiritual writer and teacher A.V. Ivanov, Nikolay (Ziorov)'s teacher from Odessa Theological Seminary, spoke about the Hierarch's Alaskan diaries: "It is impossible to read without heartfelt emotion his notes, in which he tells about his journey to the country of frost and night, to the abandoned and forgotten parishes, where no missionary had set a foot since the great enlightener of this country, Innokentiy" [14].

K. P. Pobedonostsev expressed an interesting reaction to the diary in a letter dated March 13, 1893: "I have just finished reading your Diary, which is getting more and more interesting. I've sent the notebooks to P. A. Smirnov to print. Some places will have to be excluded - with the characteristics of some scoundrels, whom you have the misfortune to have in the clergy. The picture is already very sad. I would like to speed up printing very much, so that I can still send the print to the Emperor during His stay in the Crimea, where he will have more time for reading" [15].

Bishop Nikolay (Ziorov) acted as a reformer of diocesan life in Alaska. In his desire to make the texts of the liturgical books available to all his parishioners, which was impossible without improving the level of literacy, the Hierarch appealed to the Holy Synod with a request to print the necessary number of copies of the primer. The Gospels and catechisms in the Aleutian language, modeled on publications prepared while Innokentiy (Veniaminov) was still in Alaska. Nikolay (Ziorov) himself collected several manuscripts with gospel texts and texts of the books of acts and the Apostles' Epistles in the Aleutian language, as well as translations of prayers and church hymns into the Kvikhpakh and Koloshin dialects, which he also proposed to publish in the Synodal printing house [16]. By the centenary of the Orthodox mission in Alaska, these publications had been published $[17 ; 18]$.

Another Bishop Nikolay (Ziorov)'s innovative step was to invite students of Vologda Theological Seminary to serve in Alaska. The Bishop was familiar with this spiritual and educational institution firsthand: in 18831885, he worked there as an inspector. The Bishop probably suggested that talented seminary graduates could better organize parish life in the Northern region, and the harsh climate of Alaska could not frighten people who lived in the conditions of the Russian North. One of the priests who went to the United States of America was Tikhon Nikolaevich Shalamov, the father of the writer Varlam Shalamov [19].

The special results of Nilolay (Ziorov)'s activities in North America were summed up in his report on the state of the Aleutian diocese for 1897, which was sent to the Holy Synod [20]. Many pages of this document are devoted to Alaska. Describing the Aleutian diocese as "universal", very diverse in its national composition, the Hierarch singled out the following communities among the population of the region: Aleuts, Kolos, Eskimos, Creoles. He defined the latter as "a mixture between whites and natives - Aleuts and Indians" [21]. At the same time, the Bishop placed the Aleuts above other peoples and tribes that inhabited the diocese "in their religious mood". During May, June, and July 1897, Nikolay (Ziorov) was surveying Alaska, where he visited Pribylov Islands and Mikhailovsky redoubt. Nikolay (Ziorov) noted how difficult the trip was for him: "Traveling in Alaska was accompanied by great inconveniences, if not in all, then at least in many ways. It was especially hard to feel in the Bering sea - among the eternal fogs and ice... We had to stand for a long time between the Islands of St. Matthew and St. Lawrence, among the floating blocks of ice: it was such a piercing, all-pervading cold that all the bones began to ache unbearably. After these trips to Alaska, I am now exactly shell-shocked: at the slightest atmospheric change, I feel an unpleasant sensation throughout my body, as if my body is all burned" [22]. However, despite all the difficulties, the Hierarch made the following conclusion about the Orthodox community's life in the region: "Alaska, which had been dormant for so long, has now woken up again and is beginning to claim its existence" [23]. The Bishop attributed the reason for the activation of parish life in the region to two reasons: the initiative work of the clergy who came from Russia to serve, and the publication of the "American Orthodox Bulletin", which had a beneficial effect on the flock.

Attention is drawn to Bishop Nikolay (Ziorov)'s initiative to create several monasteries in Alaska. There were no Orthodox spiritual centers of this kind in the region, and all the Hierarch's attempts to resolve this issue were met with bureaucratic delays and resistance from local authorities. His Eminence believed that the creation of monasteries in Alaska would be possible only with the assistance of the Missionary community that existed in the Russian Empire, as well as with the necessary number of active and disciplined monks, and not only "wearers of monastic hoods and robes". The Hierarch considered the Kolmak redoubt in the Kuskokwim mission and Spruce island (modern name Spruce) to be the most suitable places for opening monasteries in Alaska [24].

Nikolay (Ziorov) treated the Aleuts, whom he characterized positively and singled out among all his diverse flock, with great sympathy. In his 1897 report on the state of the diocese, he described the native inhabitants of Alaska in this way: "The good Aleuts are an exception in this case: both in joy and in sorrow they bear everything without a murmur and thank the Lord for everything... Their unselfishness, patience, complacency, mutual charity, and brotherly love are unparalleled. When I asked a priest in Alaska why they wouldn't have fraternities, he said, "We don't need them: we have a real fraternity in our entire parish! We have no beggars, for every Aleutian will always share what he has with the poor... And this is absolutely true. I myself was an eyewitness to how one 90-year-old woman - an Aleutian (Galchikha - by name) in Unalashka - was fed and watered by Aleutian families every day, in turn. To my question: "Does she ever get hungry?", she answered with surprise: "Why would I be hungry? They all feed me well; they also say: why don't you come yourself and ask, but I must send for you!" This Galchikha is a living chronicle of Unalashka and Atka, and the type of an Aleutian who embodied humility and 
kindness. This is who the Lord promised His Kingdom to! " [25]

Among the negative phenomena characteristic of Alaska, Bishop Nikolay named the oppression of government agents, hostility to the clergy on the part of trading companies, and "unscrupulous attitude of nonOrthodox missionaries and public school teachers to the population "[26]. The Hierarch regularly reported this to the Holy Synod. This issue was also regularly raised on the pages of the "American Orthodox Bulletin". For example, the article "From Unalashka" started with a characteristic question: "Will there be an end to our sorrows in Unalaska from the illegal actions of the Methodists?" It was about the fact that Orthodox children who were trained in Methodist orphanages were not allowed to go to Church during holidays, and local authorities did not pay any attention to their parents' complaints [27]. Based on this state of affairs, the author asked a number of questions: "Do we not have the right to demand that it (i.e., the Federal government - the author) would be as attentive to its own Cuba... (Alaska) as carefully it treats someone else's (Spanish) Cuba?.. And wouldn't Russia be more right to interfere in the affairs of Alaska than America would be in the affairs of Cuba? " [28]

Consequently, the correspondent of the "American Orthodox Bulletin" drew a parallel with the events of the Spanish-American war of 1898, which began after the intervention of the United States of America in the struggle for independence in Cuba.

Another article with the eloquent title "An example of outrageous violence and lawlessness (Letter to the editor)" can be attributed as material written by the Bishop himself. This material was signed with the initials M. Z., which coincides with the lay name of the Hierarch - Mikhail Ziorov. The article described the seizure of land belonging to the Church in Mikhailovsky redoubt by an Alaskan trading company [29]. Once again, the Bishop had to face the connivance of the local authorities. Protecting the rights of the mission, Nikolay (Ziorov) intended to appeal to the Central government in Washington and demand either the return of the site or monetary compensation.

The same initials, M. Z., also appeared under an article "How can this all agree with the principles of the American Constitution?", which provided information about the harassment inflicted on Orthodox communities in Alaska by local authorities and trading companies. The author noted that the declared guarantees of personal rights of citizens and freedom of speech were not actually observed. The author of the article believed that the "government guardians" were biased towards the Orthodox community's requests, but at the same time required them to obey in all decisions. The examples included an agent Brown, who forced Aleuts to marry at their own discretion. Another example of arbitrariness was this agent's misappropriation of funds, which the parishioners sent to the Alaskan spiritual Board for safekeeping.

The correspondence that ensued on this occasion lasted from 1892 to 1895 had no consequences. The forced transfer of their children to Methodist shelters caused great dissatisfaction outrage the Aleuts. At the end of the the Aleuts requested Bishop Nikolay (Ziorov) during his visit to Alaska to apply to the Russian government to be relocated to the Commander Islands, "where they will continue to enjoy peace, freedom and the same contentment in everything that they enjoyed under the Russian company" [30].

The American Orthodox press constantly published notes with examples of trampling on the interests of the Orthodox community of Alaska. Most often, they were based on messages sent by the local population and clergy to Bishop Nikolay (Ziorov) for consideration. In particular, a missionary hieromonk Anatoly from Sitka informed Hierarch that representatives of the Presbyterian mission did not allow the funeral of the deceased wife of an "Orthodox Indian" to take place, taking the body out of the coffin and dragging it down the street. No less indignation was caused by the destruction of buildings belonging to the local population and the impossibility of justice in such cases [31]. The Orthodox population of Alaska drew up a petition addressing the Russian Ambassador in Washington, Ernest Karlovich Kotzebue. In it, they complained about the iniquities committed by Presbyterian missionaries and government officials. For this reason, the Alaskans asked the diplomat to appeal to the government in Washington to comply with the terms of the 1867 Treaty between Russia and the United States of America and to respect the Orthodox. It was also suggested that the Emperor Nikolay II should apply for the appointment of a representative of the Russian government to Alaska, to whom Russian subjects and Orthodox residents of the region could apply in case of infringement of their rights, both religious and secular [32].

The «American Orthodox Bulletin» published a petition in English and Russian from the Orthodox residents of Sitka, sent to the President of the United States of America in connection with violations of the terms of the 1867 Tract [33]. The text, in particular, stated that "we know that the Russian government, when handing Alaska over to the United States, did not sell us as slaves, but provided us with certain rights and advantages that were later approved and legalized by the Congress" [34]. Sitka residents complained that the killing of indigenous people "by white people" went unpunished. At the same time, dissatisfaction with "local excesses" did not mean disloyalty to the highest state power. The authors of the petition noted that "With all that, we never lost faith in Washington government. The sad reality only made us lose faith in the people sent here by the government" [35]. Alaska residents demanded not only a ban on the seizure of their land and on hindering fishing, but also on the closure of pubs that negatively affected the state of morals in the province: "We do not want a civilization that not only does not close such institutions, but even encourages them. We do not want an education by which our daughters are separated from home and alienated, taught English, which only gives them the opportunity to practice prostitution more easily and profitably. Drunkenness brought adultery into our families, and adultery broke all the bonds that held 
family relationships together. We do not want to look at such a terrible evil with a calm spirit and indifference, but we want the crimes committed to be punished not only with easy fines, but in some way so that there is a real benefit" [36]. It is known that Bishop Nikolay (Ziorov) himself appealed to the twenty-fifth American President, William McKinley, with a request to protect his flock from illegal attacks and harassment [37].

The last journey of Bishop Nikolay (Ziorov) in Alaska lasting from May to August 1897 is described in some detail. The pages of the diocesan publication had letters of the Hierarch's companion on the trip, Psalmist Pavel Grepachevsky. They visited Unalashka, Kodiak, Mikhailovskiy redoubt and Sitka. P. Grepachevskiy describes the nature of the region: "Unfortunately, we didn't have time to admire these picturesque places for long; by the morning of May 21, we were already off the coast of the tip of the Alaskan Peninsula, the entire length of which only had bare rocks covered entirely with snow and several very high pyramid-shaped mountains of volcanic origin (the so-called fire-breathing mountains or hills); only Pavlov volcano (near Belkovsk) was seen smoking; we also came across islands of the same origin, which even now, according to sailors, are not always visible on the surface of the water" [38]. In Alaska, the Bishop visited churches, conducted services, and communicated with parishioners. In Unalashka, the travelers were surprised to note that local residents hardly celebrated the Independence Day of the United States, remembering that during the Russian rule they did not suffer from the arbitrariness of trading companies [39-42].

\section{Conclusions}

The opinion that Nikolay (Ziorov) developed while serving in North America was further demonstrated in his later work in other dioceses. To a large extent, this affected inter-ethnic and inter-religious relations. In both Tauride and Warsaw dioceses, he positioned himself as a defender of the Orthodox faith among the gentile environment. This is how during his first archpastoral visit to Tauride Theological Seminary, he gave the rector of the spiritual educational institution one hundred rubles to replenish the student library with the best works of an anti-sectarian nature [43].

However, this line of behavior did not mean disrespect for representatives of traditional faiths. As noted by Archpriest L. I. Turkevich, "Managing the churches in the Privislinsky region, Archbishop Nikolay, first of all, made efforts to avoid antagonism between the Catholic and Orthodox clergy. $<\ldots>$ His peacefulness and sobriety of views gained him great authority and love in the region among all nationalities." While leading Warsaw diocese, Nikolay (Ziorov) made a special order forbidding the delivery of warlike and divisive sermons from the church pulpits [44]. After serving in North America, the Hierarch widely practiced long trips to the dioceses entrusted to him, visiting churches and communicating with parishioners. Also, the experience of working in Alaska was taken into account when organizing missionary activities. Almost immediately after his arrival in Tauride diocese, Bishop Nikolay (Ziorov) organized a Missionary Congress, where an influential official of special assignments under the chief Prosecutor of the Holy Synod, V. M. Skvortsov, was invited. [45]. For the first time in the history of Tauride Theological Seminary, the students began studying the Crimean Tatar language, which at that time was one of the languages of interethnic communication in the Crimea [46]. An important element of the missionaries' work in the Tauride diocese was the distribution of books and pamphlets in the Crimean Tatar language that carried knowledge about Orthodoxy. Missionary work was intensified in church schools, where children of various faiths studied together.

«Niva» magazine, one of the most popular illustrated publications in the Russian Empire, in 1900, wrote about Bishop Nikolay (Ziorov)'s stay in the United States: "This arduous and responsible Ministry of his grace Bishop Nikolay continued for seven long years. Being in this great and difficult post of "Apostle of America", he worked piously for the benefit of Christianity and Orthodoxy - on the far outskirts of the world" [47]. However, these words are equally applicable to his service in Taurida and the Kingdom of Poland. It is no coincidence that one of the obituaries dedicated to the memory of the Prelate noted that "in the face of the deceased Archbishop of Warsaw Nikolay, Russian Church hierarchy has lost one of enlightened bishops, who was teaching continually, the only person rigorous about the truth of the Church and the good of his flock, a staunch and direct man, strict and demanding of himself and his subordinates in the execution of their duty, sensitive, noble and kind-hearted to the needs of the poor, the afflicted and the destitute" [48].

\section{Agreements}

The research was supported by the Russian Science Foundation grant 20-78-10044

\section{References}

1. V. V. Kalinovsky, Archbishop Nikolay (Ziorov): Crimean pages of the Hierarch's biography, Topical issues of modern theology and church science. Materials of the $4^{\text {th }}$ international scientific and theological conference dedicated to the 100th anniversary of the beginning of the martyrdom and confessional feat of the Russian Orthodox Church, 154-159 (2018)

2. V. V. Kalinovsky, Archbishop Nikolay (Ziorov)'s views on the national question, Christian reading $\mathbf{5}$, 237-250 (2019)

3. V. V. Kalinovsky, A. S. Puchenkov E. A. Samylovskaya, Service of Archbishop Dimitri (Abashidze) in the Black sea fleet, Voprosy Istorii 4, 18-33 (2020)

4. V. V. Kalinovsky, A. S. Puchenkov, Restless March of Archbishop Dimitri (Abashidze): Orthodox 
clergy of Crimea after the victory of the February revolution, Rossiiskaia Istoria 6, 162-168 (2018)

5. I.V. Petrov, A. S. Puchenkov, "Drafts of the future": the problem of anti-semitism in the ranks of the Tauride clergy in 1914-1917, Voprosy Istorii 12(2), 205-220 (2019)

6. Russian state historical archive, f. 684 , op. 1, case 32 , p. 2

7. Ibid, p. 2

8. Ibid, p. 5-5 op.

9. Russian state historical archive, f. 796, op. 205, case 491, p. 7-9 op.

10. Russian state historical archive, f. 1574, op. 2, case. 247 , p. 5-5 op.

11. Ibid, p. 13

12. Ibid, 74-74 op.

13. Nikolay, From my diary: Travel notes and impressions during a trip to Alaska and the Aleutian Islands, [Op.] by His Eminence Nikolay, Bishop of Aleutian and Alaska (Saint Petersburg: editorial office of "Church Bulletin"journal 1893)

14. A. I. Eminent Reverend Nikolay, Bishop of Tauris and Simferopol, Taurida Diocesan News 21, 14121413. (1898)

15. Russian state historical archive, f. 1574 , op. 2 , case 247 , p. 20

16. Russian state historical archive, f. 796, op. 174, case 2977, p. 1-2

17. Collection of church hymns and prayers in Koloshin dialect: edition of his grace Nikolay, Bishop of Aleutian and Alaska, in memory of the centenary of the Orthodox mission in America / translated by I. Nadezhdin. (San Francisco, 1896)

18. Prayers in the Koloshin dialect: edition of his grace Nikolay, Bishop of Aleutian and Alaskan, in memory of the centenary of the Orthodox mission in Alaska / translated by V.Donskoy (Sitkha 1895)

19. Russian state historical archive, f. 796, op. 174, case 298, p. 18.

20. Russian state historical archive, f. 796, op. 179, case 4034.

21. Ibid, p. 4 op.

22. Ibid, p. 7 op. -8

23. Ibid, p. 7 op.

24. Ibid, p. 8 op. -9

25. Ibid, p. 14 op. -15

26. Ibid, p. 20

27. N., From Unalaska, American Orthodox Bulletin 19, 552-558. (1898)

28. Ibid, p. 558

29. M.Z., An example of outrageous violence and lawlessness (Letter to the editor), American Orthodox Bulletin 23, 480-483 (1898)
30. M.Z, How can all this be reconciled with the principles of the American Constitution? American Orthodox Bulletin 11, 196-205 (1897)

31. Push, and it will open, American Orthodox Bulletin 12, 224-227 (1897)

32. Petition of the Orthodox population of Alaska about the same violence, addressed to the Russian envoy in Washington, E. K. Kotzebue, American Orthodox Bulletin 12, 240-242 (1897)

33. A petition filed with the President of the United States last fall by the Sitkin Indians over the unauthorized violation by local Americans of the terms of the 1867 Tract, American Orthodox Bulletin 12, 242-246 (1897)

34. Ibid, p. 243

35. Ibid, p. 244

36. Ibid, p. 245-246

37. Nikolay (Ziorov), His grace Nikolay, Bishop of Taurida and Simferopol, former Aleutian and Alaskan, a farewell address to the pastors of the Aleutian diocese and a farewell message to the President of the United States ( New York, 1898)

38. P. Grepachevsky, Journey of His grace, most Reverend Nikolay, Bishop of Aleutian and Alaskan, in Alaska, American Orthodox Bulletin 22, 464. (1897)

39. P. Grepachevsky, American Orthodox Bulletin 22, 460-465 (1897)

40. P. Grepachevsky, American Orthodox Bulletin 23, 484-494 (1897)

41. P. Grepachevsky, American Orthodox Bulletin 24, 519-526 (1897)

42. P. Grepachevsky, American Orthodox Bulletin 1, 18-26. (1897)

43. A. I., A visit to Tauride Seminary, Taurida Diocesan News 6, 379-387 (1899)

44. L. I. Turkevich, His Eminence Nikolay, Archbishop of Privislinsky and Warsaw, American Orthodox Bulletin 4, 52 (1916)

45. P. Tikhvinsky, Opening of the Tauride Diocesan Missionary Congress, Taurida Diocesan News 11, 798-809 (1899)

46. Report of the Taurida Committee of the Orthodox missionary society for 1903, Taurida Diocesan News 4, 247-253. (1904)

47. His grace Nikolay, Bishop of Taurida, Niva 47, 941 (1900)

48. His Eminence Nikolay, Archbishop of Warsaw and Privislinsky + December 20, 1915 (obituary), Kherson Diocesan News. The Department unofficial 1, 18 (1916) 